\title{
Histological and Biochemical Parameters Follow-up in Experimental rats Administrated dexamethasone and Treated with Green Synthesis Titanium Dioxide Nanoparticles Using (Camillia sciences) Extracts
}

\author{
Amal K. Abbas ${ }^{1}$ \\ Nada K. Abbas ${ }^{2 *}$ \\ Ruaa M. $A$ Ii $^{2}$ \\ Lamia K. Abbas ${ }^{3}$
}

Received 6/9/2019, Accepted 23/10/2019, Published 23/6/2020

This work is licensed under a Creative Commons Attribution 4.0 International License.

\begin{abstract}
:
In this study, Titanium Dioxide Nanoparticles were synthesized by an easy and eco-friendly technique (green synthesis) using green tea leaves (Camillia sinensis), Nanoparticles were analyzed using structural and optical analysis, the X-ray pattern showed that Titanium Dioxide NPs had a tetragonal structure with (Face Centered Tetragonal) FCT crystal structure, the UV-visible recorded an absorbance peak near $350 \mathrm{~nm}$ and calculated energy band gap was $3.5 \mathrm{eV}$, all measurements were proved the purity and Nano size of prepared Nanoparticles. Biochemical parameters evaluation also mentioned in this research, these analyzes showed that Titanium Dioxide nanoparticles in particular dose $(50 \mathrm{mg} / \mathrm{kg})$ have the ability to reduce blood glucose levels, improve liver functions and recover lipid levels in the animals body, and lastly, histological pancreatic parts were submitted to observe changes that occurred after dexamethasone and nanoparticles were injected.
\end{abstract}

Key words: Dexamethasone, Lipids, Liver enzymes, Titanium Dioxide Nanoparticles(TiO2 NPs), X-ray diffraction (XRD).

\section{Introduction:}

There are various synthetic methods have been reported by researchers to synthesize nanoparticles mainly divided into three classes, physical, chemical and biological methods (1). In the conventional synthetic method, both physical and chemical often required reducing agent and stabilizing agent that are unfriendly and highly toxic to the surrounding environment. Besides, these methods are also costly, high energy consumption and the high possibility for the formation of toxic products (2). Nanoparticles appear high improvement in physical and chemical properties compared with bulk, such as energy gap (3). Varieties of living organisms are used as "biofactories" for the synthesis of different forms of nanoparticles. Plants give a specific option for the synthesis of nanoparticles among biological systems (4).

${ }^{\mathrm{T}}$ Department of Biology, College of Science, University of Baghdad, Baghdad, Iraq.

${ }^{2}$ Department of Physics, College of Science for Women, University of Baghdad, Baghdad, Iraq.

${ }^{3}$ Department of Physics, College of Science, University of Baghdad, Baghdad, Iraq.

"Corresponding author: nadabbs@yahoo.com

"ORCID ID: https://orcid.org/0000-0001-8573-4174
The use of environmentally benign material like plant extract (leave, flower, bark, seed, peels etc.), fungi, bacteria, and enzyme for the synthesis of nanoparticles offers numerous benefits of ecofriendliness and compatibility for pharmaceutical and other biomedical applications as they do not use toxic chemical for the synthesis protocol (5). Titanium dioxide $\left(\mathrm{TiO}_{2}\right)$ is an inert, nontoxic and inexpensive material whose high refractive index and high capability to absorb UV light make it an interesting white pigment and environmentally friendly catalyst and can be absorbed into the body by inhalation, ingestion and dermal penetration due to their small size (6), $\mathrm{TiO}_{2}$ nanoparticles also can penetrate the liver cell (7).

Dexamethasone is an artificial corticosteroid similar to steroid hormone cortisol. Large quantities of corticosteroids administered for a long time to animals that cause infections such as diabetes (8), Dexamethasone has many side effects including the potential to increase blood glucose levels postoperatively, which is a known risk factor for complications after total joint arthroplasty (9). The use of plant extract is preferable as they are easily available; save to handle and possess a broad viability of metabolites, the choice of plant extracts to produce NPs is based on the added value of the 
biological material itself (10), biosynthetic procedures can provide Nanoparticles of a better size and morphology than several physicochemical preparation processes. Plant extracts can work as a reducing agent and as stabilizing agents in the synthesis of Nanoparticles $(11,12)$.

This study aims to prepare titanium dioxide nanoparticles and estimates its activity on the liver functions and lipid profile for experimental rats administrated dexamethasone drug.

\section{Materials and Methods:}

One $\mathrm{mL}$ of Deionized Water (DW) was mixed with Titanium Dioxide bulk particles (400$800 \mathrm{~nm})(0.06 \mathrm{M})$, then they placed on hot plate magnetic stirrer at $50{ }^{\circ} \mathrm{C}$ and $1500 \mathrm{rpm}$ for few minutes. After that, $(20 \mathrm{~mL})$ of previously prepared green tea extract added to the solution gradually and allowed to cool for room temperature, the solution was centrifuged at $4000 \mathrm{rpm}$ for $15 \mathrm{~min}$. The precipitate formed was washed with DW many times and then centrifuged at $4000 \mathrm{rpm}$ for $10 \mathrm{~min}$. The obtained precipitate was dried at air oven for $2 \mathrm{~h}$ at $60^{\circ} \mathrm{C}$.

\section{Experimental animals:}

Forty eight Male adult Wister albino rats weighing (175-225g) and 10-14 weeks old housed in cages made from polypropylene under controlled conditions $25 \pm 5{ }^{\circ} \mathrm{C}$ and $12 / 12 \mathrm{hrs}$ light/dark cycles, drinking water and Diet food were given ad libitum, the animals were reared and treated in University of Baghdad /animal house in college of science,.

Experimental animals had randomly divided into six groups, each group contained eight rats $(n=8)$ treated for 30 days, and intended as follows: G1 the first group was served as negative control, G2 the second group was injected intraperitoneally with $(0.5 \mathrm{mg} / \mathrm{kg})$ dexamethasone sodium phosphate, G3 and G4 were injected intraperitoneally with $(50$ and 100$) \mathrm{mg} / \mathrm{kg} \mathrm{TiO}_{2}$ Nanoparticles (13) and $(0.5 \mathrm{mg} / \mathrm{kg})$ of dexamethasone respectively, G5 was injected intraperitoneally with $50 \mathrm{mg} / \mathrm{kg} \mathrm{TiO}{ }_{2}$ Nanoparticles and G6 injected intraperitoneally with $100 \mathrm{mg} / \mathrm{kg}$ $\mathrm{TiO}_{2}$ Nanoparticles.

The Laboratory animals have fasted $24 \mathrm{hrs}$ before dexamethasone injection; they were weighed and anesthetized by inhalation in a glass dome.

\section{Biochemical analysis, statistical analysis and histological Examinations}

When experience period end; blood samples collected from animals by heart puncture way, the blood was centrifuged at $4000 \mathrm{rpm}$ for 10 min, serum was separated for test of several biochemical parameters such as blood glucose level (BGL) measured by commercially kit (Biosystem, Germany), cholesterol (TC), High Density Lipoprotein Cholesterol (HDL-C), Triglyceride (TG) and Low Density Lipoprotein Cholesterol (LDL-C) estimated using a commercially available kit (Linear kit, Spain), serum levels Alanine Aminotransferase (ALT), Aspartate Amina transferase (AST), Alkaline Phosphate (ALP) and Total Bilirubin (TB) were assessed using commercially available kit (Reflotron kit, Germany). Results were stated as means \pm standard Errors. The Statistical Analysis System applied using one way (ANOVA) analysis of variance to verify the Least Significant Difference (LSD), All figures were drawn by the Statistical Package of Prism software 8.1.2 (Version 8.1.2, GraphPad, San Diego, CA, USA). The Probability (P) value $\leq 0.05$ has been considered to be of statistical significance.

Pancreatic Samples were collected from animals after organs separation and fixed in $10 \%$ buffered neutral formalin solution, dehydrated in gradual ethanol $(70 \%)$, cleared in xylene, and embedded in paraffin. $5 \mu \mathrm{m}$ thick paraffin sections were prepared and then regularly stained with Hematoxylin and Eosin (H\&E) (14) and then examined microscopically.

\section{Results and Discussion:}

Nano-powder structural characterization was recorded by Pro Penalty CAL with $\mathrm{Cu}-\mathrm{K \alpha}$ radiation (1.5406 ̊) XRD models, Tab.1, and Fig.1 illustrate X-ray diffraction (XRD) pattern of as synthesized $\mathrm{TiO}_{2}$ Nanoparticles and standard X-ray pattern of $\mathrm{TiO}_{2}$. Peaks obtained at $2 \theta$ values from $25.32^{\circ}$ to $76.11^{\circ}$ indicated tetragonal structure with FCT crystal structure of anatase $\mathrm{TiO}_{2}$ nanoparticles (JCPDS No. 21-1272), The average crystallite size of $\mathrm{TiO}_{2}$ was $11.82 \mathrm{~nm}$ calculated using Scherer relation $(15)(\mathrm{C} . S=(0.9 \lambda) /(\beta \operatorname{Cos} \theta))$ where C.S is Crystallite Size measured in nanometers, $\beta$ Full Width at Half Maximum measured in radian, $\lambda$ wavelength of $\mathrm{x}$ ray measured in nanometers. And the lattice parameters of the pure $\mathrm{TiO}_{2}$ nanoparticle is $(a=b=3.79 \AA, c=9.52 \AA)$ which equivalents to the lattice parameter of bulk $\mathrm{TiO}_{2} \quad(\mathrm{a}=\mathrm{b}=3.7850 \AA$, $c=9.5196 \AA)$, broadening (Enlargement) of the peaks is due to the crystalline size of sample is very small, the obtained values is agreed with (16). 
Table 1. The structural parameters of the as synthesized $\mathrm{TiO}_{2}$ Nanoparticles

\begin{tabular}{cccccc}
\hline $2 \theta($ Deg.) & C.S $(\mathrm{nm})$ & FWHM $($ Deg. $)$ & $\mathrm{d}_{\text {hkl }}$ Exp. $(\AA)$ & $\mathrm{d}_{\text {hkl }}$ standard $(\AA)$ & $(\mathrm{hkl})$ \\
\hline 25.32 & 9.2 & 0.877 & 3.517 & 3.585 & $(011)$ \\
36.97 & 5.7 & 1.398 & 2.431 & 2.427 & $(013)$ \\
37.80 & 39.8 & 0.200 & 2.379 & 2.376 & $(004)$ \\
38.59 & 5.7 & 1.398 & 2.332 & 2.3345 & $(112)$ \\
48.08 & 5.79 & 1.372 & 1.892 & 1.842 & $(020)$ \\
53.91 & 7.33 & 1.086 & 1.700 & 1.680 & $(015)$ \\
55.11 & 7.25 & 1.100 & 1.666 & 1.664 & $(121)$ \\
62.99 & 9.9 & 0.808 & 1.481 & 1.474 & $(024)$ \\
68.76 & 7.25 & 0.100 & 1.364 & 1.364 & $(116)$ \\
70.56 & 15.96 & 0.498 & 1.338 & 1.333 & $(220)$ \\
74.05 & 17.65 & 0.450 & 1.279 & 1.279 & $(017)$ \\
75.10 & 6.96 & 1.142 & 1.265 & 1.274 & $(125)$ \\
76.11 & 15.28 & 0.520 & 1.250 & 1.246 & $(031)$ \\
\hline
\end{tabular}
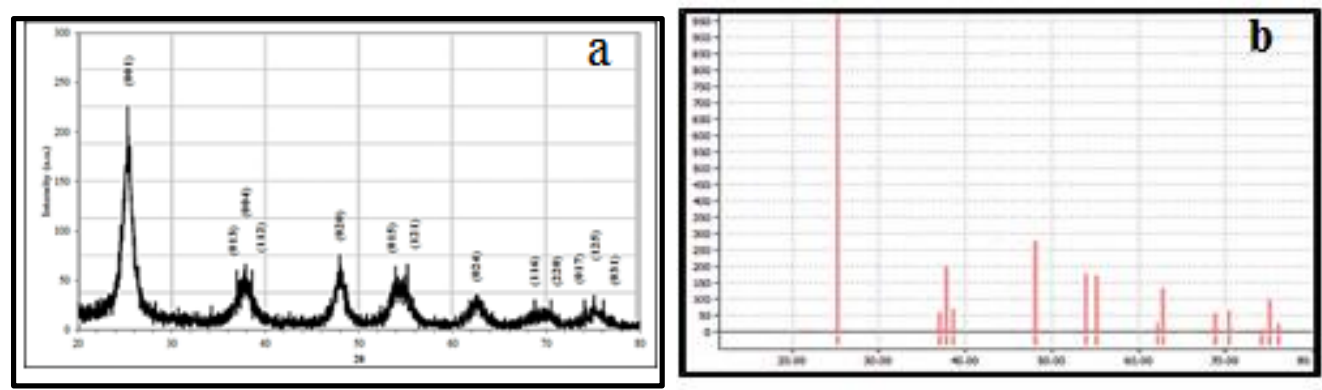

Figure 1. XRD pattern of the (a) as synthesized $\mathrm{TiO}_{2}$ Nanoparticles (b) standard XRD peaks positions pattern of $\mathrm{TiO}_{2}$

The optical behavior measured by VARIAN spectrophotometer (Cary 5000 Scan), absorbance and optical energy bandgap have been recorded for as-synthesized Titanium Dioxide Nanoparticles solution, Fig. 2 shows the maximum absorption depends on the size of the nanoparticles; calculated bandgap from Planck's relation (17) $(\Delta \mathrm{E}$ $=\mathrm{hc} / \lambda$ ) was $3.5 \mathrm{eV}$ at wavelength Maximum $350 \mathrm{~nm}$ corresponds to absorption peak, Where, ' $h$ ' represented the Planks constant, 'c' denoted speed of light and $\lambda$ represented the maximum wavelength, From the current results, the present energy bandgap was shifted towards blue region spectra when this value compared to energy gap of bulk which may happened by the quantum confinement effect, and the Maximum peak is represent Surface Plasmon Resonance SPR.

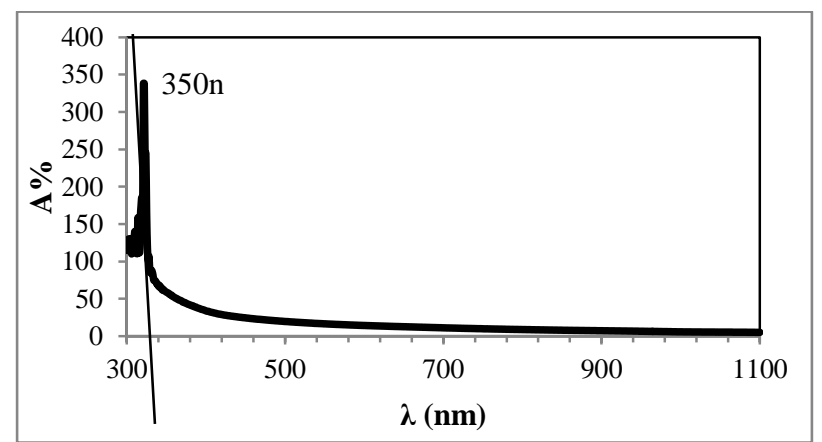

Figure 2. Absorption Spectrum of $\mathrm{TiO}_{2}$ Nanoparticles
The biochemical results $\mathrm{p}$ resented a significant differences between control and treated groups, Table 2 and Fig $3 \mathrm{a}$ indicated a significant increase $(\mathrm{P} \leq 0.05)$ of blood glucose level (BGL) in group which treated by dexamethasone $(\mathrm{G} 2)$ compared with negative control group (G1), these results agreed with the previous studies (18) in which reported that dexamethasone caused tissue damage in pancreas which leads to decrease insulin secretion from Langerhans cells, oxidative stress is the reason of creation ROS, The generated ROS or free radicals is damage cellular membranes, proteins and nucleic acids. Chronic hyperglycemia is toxic to the body because of the auto oxidation of glucose that produces strong ROS hydrogen peroxide $\left(\mathrm{H}_{2} \mathrm{O}_{2}\right)(19)$.

Nanoparticles treatment showed significant $(\mathrm{P} \leq 0.05) \quad$ BGL decreases for $50 \mathrm{mg} / \mathrm{kg}$, this reduction may be due to the ability of nanoparticles to delaying or inhibiting the absorption of glucose in the intestines (20), Stimulate insulin secretion from pancreas cells (21) the second dose of $\mathrm{TiO}_{2}$ nanoparticles (G4) $100 \mathrm{mg} / \mathrm{kg}$, wasn't significant because the high dose of $\mathrm{TiO}_{2}$ Nanoparticles may be cause cytotoxicity that affecting cellular functions such as cell proliferation, differentiation and mobility resulting in apoptosis (22). (G5 \& G6) which injected by nanoparticles were found to be near normal BGL range. 
Table 2. Changes of Serum biochemical parameters in treated rats with $\mathrm{TiO}_{2}$ Nanoparticles after 30 days, Each value represents the mean \pm standard error of $(n=8)$, The values found to be significant at $\mathbf{P} \leq 0.05,\left({ }^{*} \mathbf{P}<0.02, * * \mathbf{P}<0.001, * * * \mathbf{P}<0.0008, * * * * \mathbf{P}<0.0001\right)$

\begin{tabular}{lcccccc}
\hline & \multicolumn{7}{c}{ Groups } & G1 & G2 & G3 & G4 & G5 & G6 \\
Parameters & & & & & & $161.2 \pm 5.4^{* *}$ \\
BGL (mg/dL) & $113.2 \pm 6.4$ & $395.2 \pm 29.7$ & $167.7 \pm 2.9^{* *}$ & $302.7 \pm 7.7$ & $123.5 \pm 2.5$ & $49 \pm 3.6$ \\
ALT(IU/L) & $35.7 \pm 1.6$ & $66.2 \pm 4.7$ & $40.2 \pm 1.3^{* *}$ & $47 \pm 2.1$ & $38.2 \pm 1.3$ & $42 \pm 0.7 *$ \\
AST(IU/L) & $27.2 \pm 4.4$ & $48.2 \pm 3.5$ & $35 \pm 1.6^{*}$ & $45.7 \pm 2.2$ & $35 \pm 1.9$ & $2315 \pm 24.6$ \\
ALP(IU/L) & $151 \pm 17.8$ & $383.2 \pm 30.7$ & $222.2 \pm 5.8^{* *}$ & $346.5 \pm 2.3$ & $194 \pm 3.5$ & $0.93 \pm 0.03^{* * *}$ \\
TB(mg/dL) & $0.33 \pm 0.01$ & $1.42 \pm 0.08$ & $0.61 \pm 0.04^{* *}$ & $1.2 \pm 0.1$ & $0.63 \pm 0.02^{* *}$ & $197.7 \pm 0.8$ \\
TC(mg/dL) & $178.5 \pm 12.5$ & $255 \pm 5.4$ & $181.7 \pm 4.5^{* *}$ & $213.5 \pm 5.7 *$ & $191 \pm 2.6$ & $177.7 \pm 2.8$ \\
TG(mg/dL) & $152.2 \pm 10$ & $231.7 \pm 14.8$ & $161.7 \pm 4.6^{*}$ & $195.2 \pm 2.5$ & $161.7 \pm 20$ & $38.2 \pm 0.8^{*}$ \\
HDL-C(mg/dL) & $45 \pm 1.6$ & $26 \pm 3$ & $42 \pm 2^{*}$ & $29.7 \pm 2.1$ & $43.2 \pm 1.3$ & 1.3 \\
LDL-C(mg/dL) & $91.2 \pm 8.1$ & $172 \pm 13.1$ & $110 \pm 2.1^{*}$ & $166.5 \pm 2.5$ & $138.7 \pm 1.6^{*}$ & $146.2 \pm 4.1 *$ \\
\hline
\end{tabular}

Table 2 and Figs. 3b, c, d and e, displayed increases in liver enzymes and TB in G2 which injected by $0.5 \mathrm{mg} / \mathrm{kg}$ dexamethasone, these raises recorded because of enzymes leakage from cytosol into the bloodstream because of hepatic damage associated with dexamethasone, ALT and AST levels increased is associated with insulin deficiency has been interrelated to increased gluconeogenesis (23).

After treating with $50 \mathrm{mg} / \mathrm{kg}$ these levels were decreases and their reduction were statically significant $(\mathrm{P} \leq 0.05)$ in $\mathrm{G} 3$, while $\mathrm{G} 4$ that treated with $100 \mathrm{mg} / \mathrm{kg}$ had no significant effects, G5 and G6 had normal levels. As shown in Table. 2 and Figs 3f, g, h and i; (G2) had TC increase attributed increasing the activity of (Lecithin-cholesterol acyltransferase) that responsible of cholesterol Absorption in intestines which stimulates in the absence of insulin (24). Treatment with $\mathrm{TiO}_{2}$ nanoparticles presented significant TC decrease $(\mathrm{P} \leq$ 0.05 ) in G3 and G4 compared with control group, the administration of high dose of $\mathrm{TiO}_{2} \mathrm{NPs}$ may deposit in the liver and leads to hepatic damage conformed by the fluctuations in hepatic marker.

This study also showed that dexamethasone was resulted an increases of TG and LDL-C compared to its level in G1, while there was a significant decrease $(\mathrm{P} \leq 0.05)$ when groups treated with nanoparticles this reduction may be occurs due to activation of lipase enzyme in the adipose tissue by nanoparticles, which acts to dissolve triglycerides into fatty acids that are absorbed by the cells. HDL-C was decreased after dexamethasone injection in $\mathrm{G} 2$ and there was a significant increase $(\mathrm{P} \leq 0.05)$ of its level in $\mathrm{G} 3$, these results are similar to $(25)$ results.

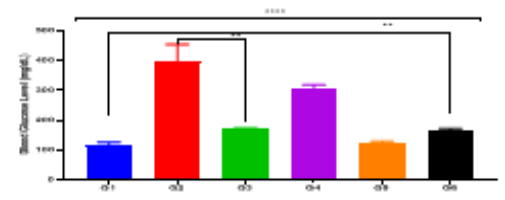

a

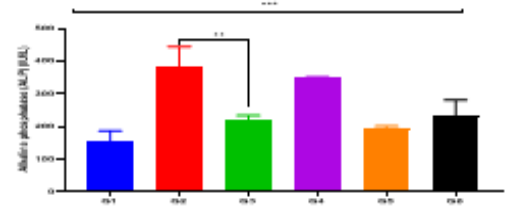

d

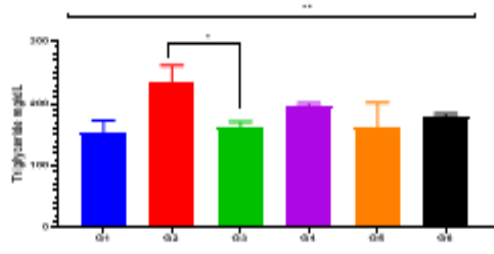

g

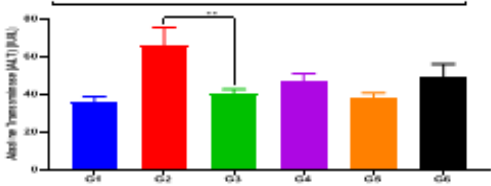

b

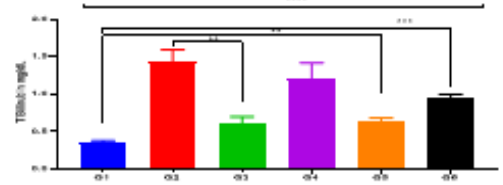

e

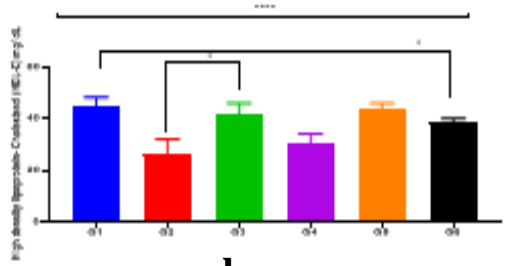

h

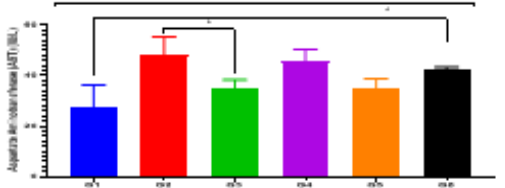

C
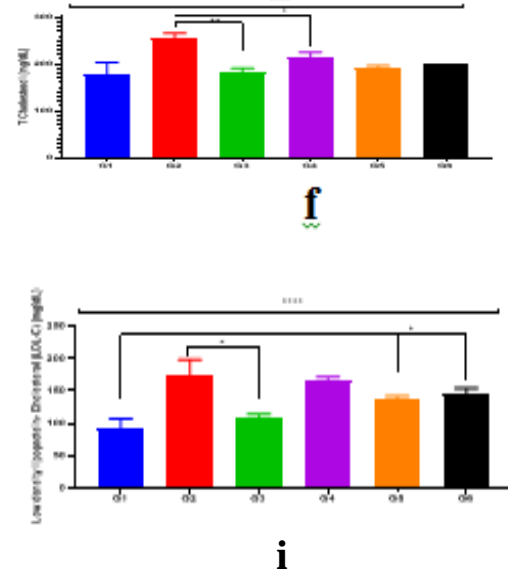

Figure 3. (a) Blood glucose mg/dL (b) Alanine Transaminase (c) Aspartate Aminotransferase (d) Alkaline Phosphatase (IU/L) (e) Total bilirubin (f) Cholesterol (g) Triglycerides (h) High density lipoprotein-cholesterol (i) Low density lipoprotein-cholesterol (mg/dL) for studied groups 


\section{Histological examination}

The cells of pancreas in negative control rats were packed closely. When dexamethasone administrated in group two; the density of cells was significantly reduced. In case of Titanium Dioxide NPs treated in group three; it was observed that the spaces in cells produced by the dexamethasone induced necrosis is decreased, similar effects of alloxan on pancreatic cells were observed in previous studies (26).

The histological sections showed different alterations of rat's pancreas many histological changes were absorbed in pancreas section of (G2) that administrated by dexamethasone, such as necrosis and damage of endocrine cells of islet Langerhans with shrinkage of islets as in Figs. 4 a, b and c, Dexamethasone induced necrosis is mediated by reactive oxygen species mediated lipid peroxidation which causes bursting of plasma membrane of the cell and disturbance of osmotic balance this osmotic alteration ultimately leads the cell towards necrosis.

Also the histological section shows different change in pancreas of rats that administrated with dexamethasone and $\mathrm{TiO}_{2}$ Nanoparticles (G3), the healing effect of Nanoparticles in Fig.5a photomicrograph it is observed that the empty spaces in islets created by dexamethasone significantly decreased; this indicates that Nanoparticles stimulates the regeneration of the damaged islets, Fig. 5b presented more damage and necrosis of endocrine cells and islets in comparison with dexamethasone treated animals, while Figs. 5c and d, shows that Nanoparticles kept normal shape of pancreatic cells and they look like normal.

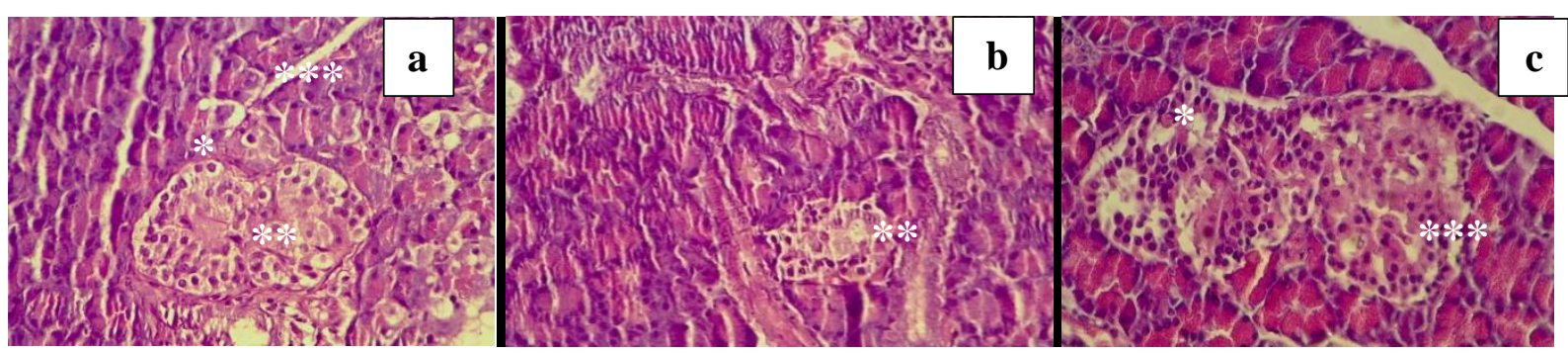

Figure 4. Cross sections of histological features of rat pancreas: (a) Photomicrograph section in the rat pancreas for Control group (G1), pancreatic lobules containing acini(*), islets of Langerhans (**) and unstained connective tissue septa $(* * *)$.(b and c) Photomicrograph section of rats pancreas $(0.5$ $\mathrm{mg} / \mathrm{kg}$ ) dexamethasone (G2), showing damage and necrosis of endocrine cells of islet (*), Langerhans with shrinkage of islet $(* *)$, degenerated acini cells and islet of Langerhans $(* * *)$ X400 (H\&E)
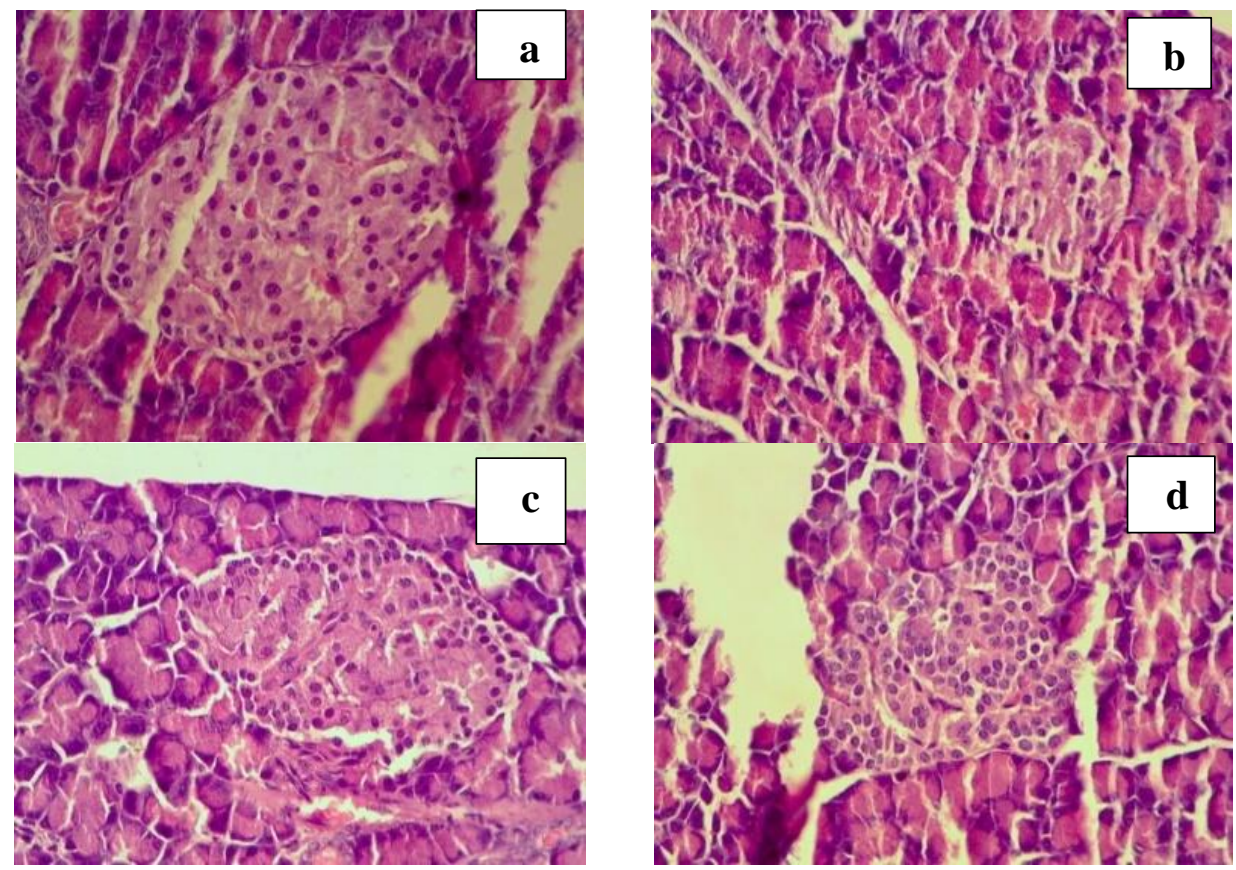

Figure 5. Cross section of pancreas cells (a) G3 (b) G4 (c) G5 (d) G6 X400 (H\&E). 


\section{Conclusion:}

This paper contains green synthesis of biocompatible Titanium Dioxide Nanoparticles by simple green procedure using green tea extract (Camellia Sinensis). The formation of nanoparticles was examined by applying structural and optical measurements, $(50 \mathrm{mg} / \mathrm{kg})$ of $\mathrm{TiO}_{2}$ nanoparticles provided a significant reduction against BGL after dexamethasone injection, using nanoparticles improved Lever enzymes, Bilirubin and lipids profile levels to confirm this results the histological staining of pancreatic section has performed, the other dose of titanium Dioxide NPs $100 \mathrm{mg} / \mathrm{kg}$, didn't show activity on pancreas islets and it had no effect on liver function and body lipids.

\section{Authors' declaration:}

- Conflicts of Interest: None.

- We hereby confirm that all the Figures and Tables in the manuscript are mine ours. Besides, the Figures and images, which are not mine ours, have been given the permission for republication attached with the manuscript.

- The author has signed an animal welfare statement.

- Ethical Clearance: The project was approved by the local ethical committee in University of Baghdad.

\section{References:}

1. Kumar R, Singh V P, Maurya D, Pandey A K. Bionanoparticles: a green nanochemical approach. Pharma Tutor. 2015; 3(9), 2835.

2. Senthilkumar S R, Sivakumar T. Green tea (Camellia sinensis) mediated synthesis of zinc oxide $(\mathrm{ZnO})$ nanoparticles and studies on their antimicrobial activities. IJ OPAPS. 2014;6(6), 461-465.

3. Nada K A, Zainab J S, Teeba H M, Lamia K A. Fabrication of $\mathrm{Cu}$ doped $\mathrm{ZnO}$ Nanoparticles for solar cell application. B S J. 2018; 15(2).

4. Ingale A G, Chaudhari AN, Biogenic synthesis of nanoparticles and potential applications: an ecofriendly approach, Ingale and Chaudhari. J Nanomed Nanotechol. 2013; 4(2).

5. Vijaylaxmee M, Richa S, Nakuleshawar DJ, Deepak KG. A Review on Green Synthesis of Nanoparticles and Evaluation of Antimicrobial Activity. IJGHC. 2014; 3, No.1, 081-094.

6. Renata D, Synthesis of Titanium Dioxide Nanoparticles Using Echinacea purpurea Herba. I J P R. 2017; 16 (2): 753-759.

7. Eman E A, Kamal M K, Hekmat O A, Eman K N, Eman E R. Histological Effects of Titanium Dioxide Nanoparticles in Adult Male Albino Rat Liver and Possible Prophylactic Effects of Milk Thistle Seeds. Life Sci J. 2015;12(2).

8. Maradit K H. Diabetes mellitus, hyperglycemia, hemoglobin A1C and the risk of prosthetic joint infections in total hip and knee arthroplasty. J Arthroplast. 2015; 30:439-43.

9. Robert S O, Bryce N C, Erin E D, Francesco S C, Gregory J G. Dexamethasone and postoperative hyperglycemia in diabetics undergoing elective hip or knee arthroplasty: a case control study in 238 patients. 2018; 12-30.

10. Imtiyaz H N. Green synthesis of nanoparticles and its potential application. Biotechnol Lett. 2016; 38:545560.

11. Ahmed S, Ahmad M, Swami B L, Ikram S. A review on plants extract mediated synthesis of silver nanoparticles for antimicrobial applications: a green expertise. J A R. 2016; 7, 17-28.

12. Nada K A, Israa A, Shurooq S M. Enhanced synthesis of biogenic silver Nanoparticles by microwave radiation and its antibacterial activity. I JN S. 2018;9(50):0976:0997.

13. Vasantharaja D, Ramalingam V,Reddy GA. Oral toxic exposure of titanium dioxide nanoparticles on serum biochemical changes in adult male Wistar rats, 2015; 2(1), 46-53.

14. Bancroft J D, Gamble M, Theory and Practice of Histological Technique. 2008;4th Ed.; Chur A A chill: Livingston, NY, USA.

15. Mosa A A. Nano Technology principle and application. academic press, 2009, Universities of technology, Iraq

16. Santhoshkumar T, Rahuman AA, Jayaseelan C, Rajakumar G, Marimuthu S, Kirthi AV, et.al. Green synthesis of titanium dioxide nanoparticles using Psidium guajava extract and its antibacterial and antioxidant properties. Asian Pacific journal of tropical medicine. 2014 Dec 1;7(12):968-76.

17. Alkauskas A, Pasquarello A. Band-edge problem in the theoretical determination of defect energy levels: The $\mathrm{O}$ vacancy in $\mathrm{ZnO}$ as a benchmark case. J. Phys. Rev. B. 2011; 84-125206.

18. Karmakar R, Chatak S, Haidar A, Bhaltacharya S. Predenisolone-induced alteration in hepatic and muscular protein and glycogen level. Its correlation with blood glucose level in mice. Folia Biol. Prague. 1998; 44(6):217-225.

19. Nita M, Grzybowski A. The role of the reactive oxygen species and oxidative stress in the pathomechanism of the age-related ocular diseases and other pathologies of the anterior and posterior eye segments in adults. Oxidative Medicine and Cellular Longevity. 2016; Article ID 3164734, 23.

20. Anderson J, Akonji A .Dietary fiber- an overview. Diab.Care. 1991;14 :1126-1131.

21. Noor H, Hammands P, Sutton R, Ashcroft S.The hypoglycaemic and insulinotropic activity of Tinospora crispa: studies with human and rat islets and HIT-T15 B cells. Diabetolo. 1989; 32 :354-359.

22. Kiss B, Bíró T, Czifra G, Tóth BI, Kertész Z, Szikszai Z, et.al. Investigation of micronized titanium dioxide penetration in human skin xenografts and its effect on cellular functions of human skin-derived cells. Experimental dermatology. 2008 Aug; 17(8):659-67. 
23. Nabi SA, Kasetti RB, Sirasanagandla S, Tilak TK, Kumar MV, Rao CA. Antidiabetic and antihyperlipidemic activity of Piper longum root aqueous extract in STZ induced diabetic rats. BMC Complement Altern Med. 2013;13(37), 1472-6882.

24. Maechler P, WollheimC, Bentzen C, NiesorsE. Importance exogenous cholesterol in diabetic rats : effect of treatment with insulin or with an acyl-Co-A : cholesterol acyl transferase inhibtor. Ann. Nutr. Metab. 1993; 37:99-209.
25. Amel M K, Raneen K T, ShoubY H, Shayma`a J A, Marawa M A. Lipid profile of Hyperlipidemic mice induced by dexamethasone treated with 105 herbals oil mixture. Diyala J O M, 2016; 11(1), 24-31.

26. Kinkar S B , Patil K G. Histological structure of pancreas in normal control, diabetic control and extract treated Albino rats. Int. J. Life Sci. 2016;4 (1): $78-82$.

\section{متابعة بعض العوامل الكيموحيوية والنسيجية في الجرذان المختبرية المعاملة بمادة الديكساميثازون

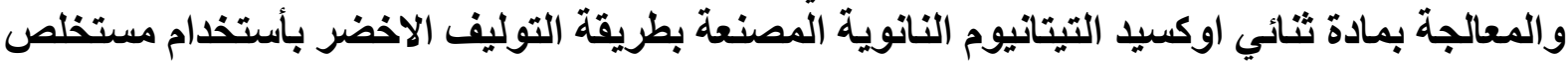 الشاي الاخضر المنعة بطر}

لمياء خضير عباس3
ندى خضير عباس2

امال خضير عباس 1

1 1 قسم علوم الحياة، كلية العلوم، جامعة بغداد، بغداد، العراق.

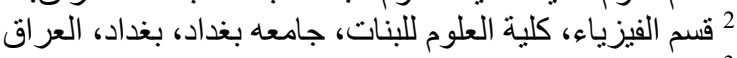

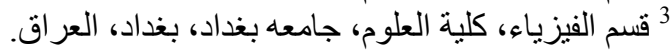

في هذه الدراسة تم تحضير ثنائي اوكسيد التينانيوم النانوي عن طريق تقنية سهلة وصديقة للبيئة هي طريقة التوليف الخضراء

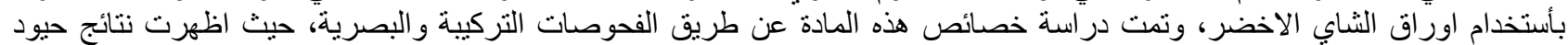

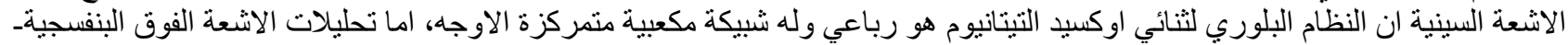

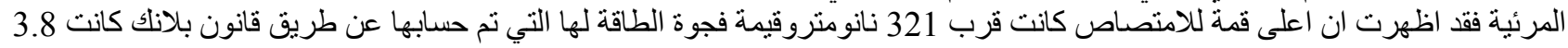

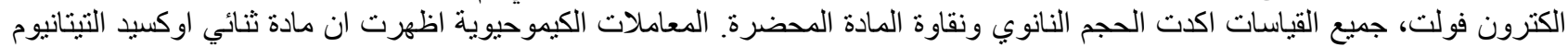

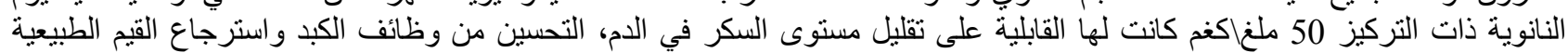

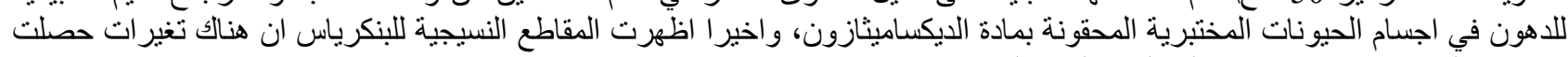
بعد حقن الديكساميثازون ومن ثم المعالجة بالمادة النانوية.

الكلمات المفتاحية: ديكساميثازون، الدهون، أنزيمات الكبد، جسيمات TiO2 النانوية، XRD. 